\title{
A Word From the Editor
}

I'm delighted to bring you another interesting collection of articles related to the teaching and learning of English as a second language in Canada. Thanks to all those who have submitted manuscripts to the TESL Canada Journal for consideration and to those who have reviewed them. This journal would not exist without your ongoing support.

I would like to officially welcome Eileen Eckert to the TESL Canada Journal as our Technical Editor. Eileen brings extensive experience in copyediting, layout, and design from her work with several other academic journals, and we are very pleased to be working with her. We are also grateful for the wonderful support provided to the journal by Wendy Chambers, who has served as acting Executive Director of TESL Canada over the past six months, and Liz Karra, who has also provided administrative support in the national office. Many individuals play specific and crucial roles in the production of the journal, and we are grateful to them for their skills and dedication.

The articles in this issue cover a range of topics that have implications for teaching and learning ESL in Canada. The first, by Antonella Valeo and Farahnaz Faez, presents the results of a survey and interviews with novice teachers who are entering the adult ESL profession following TESL education in Ontario. They describe the professional backgrounds, employment experiences, and self-efficacy of novice ESL teachers and the extent to which participants were able to secure appropriate positions within the profession in Ontario within three years of their accreditation. This article should be of interest to ESL program administrators and instructors, funders, professional associations, and TESL programs.

Sabrina Di Loreto and Kim McDonough share findings from a study conducted in ESL high schools in Quebec. They describe how the provision of practice exams and feedback on particular aspects of writing those exams increased students' perceptions of confidence and alleviated their anxiety in taking standardized integrative writing exams. They also provide practical suggestions for preparing students for these particular writing tasks, supplying instructor feedback, and enhancing student success.

Sasan Baleghizadeh and Atieh Masoun report the results of a study conducted with EFL learners on the influence of learners' formative self-assessment on their self-efficacy. Findings showed that the students who completed biweekly self-assessments achieved higher levels of self-efficacy over time. Implications and questionnaires for the use of self-assessment in post-secondary English language classes are provided and will be of interest to instructors of both ESL and EFL.

Shira Packer and Dana Lynch explore the perceptions of Canadian-born and internationally born post-secondary students and recent graduates regarding the personality of people in Canada. Findings from their survey and 
e-interviews revealed some differences in the perceptions of the two groups. The authors provide suggestions for addressing and nurturing international students' acculturation process in Canada.

An issue of continuing concern in post-secondary institutions in Canada is student plagiarism. Ismaeil Fazel and Nasrin Kowkabi identify five potential factors that contribute to incidents of plagiarism by second language learners. For each of these factors, they provide pedagogical advice based on the literature and their teaching experiences. Discussion items and online references to help students cite sources appropriately are included.

Within the current issue we also have reviews of Jill Bell's New Language, New Literacy (by Marilyn Abbott), Thomas Farrell's Reflective Writing for Language Teachers (by Justine Light), and Bonny Norton's Identity and Language Learning: Extending the Conversation (by John Sivell and Chirawibha Sivell). We hope that these reviews will lead you to read the original works and take advantage of the wealth of information that they offer ESL practitioners.

There is much food for thought within the pages of this issue. We'd like to suggest that, if you're not currently part of a professional reading group, you recruit a few colleagues, choose one of the articles in this issue that is of common interest to you, and then meet to discuss it. Set a fixed time for the informal meeting (e.g., an hour), hold it in a comfortable environment, and be sure to include social time and refreshments. By identifying and discussing the implications of the article for ESL classes in your particular context, you will have an opportunity to share your own classroom experiences and to apply some of them in coming weeks. I hope that this will be an enriching experience in your ongoing professional development. Happy reading!

Marian Rossiter 


\section{Un mot de l'éditrice}

Il me fait très plaisir de vous présenter une autre collection intéressante d'articles relatifs à l'enseignement et l'apprentissage de l'anglais langue seconde au Canada. Un grand merci à tous ceux et à toutes celles qui ont soumis des manuscrits à la Revue TESL du Canada ainsi qu'aux réviseur(e)s. Cette revue ne pourrait exister sans votre appui continu.

Je tiens à souhaiter la bienvenue officielle à Eileen Eckert, la nouvelle rédactrice technique de la Revue TESL du Canada. Eileen arrive avec une vaste expérience en édition, mise en page et conception découlant de son travail avec plusieurs autres revues académiques, et nous sommes très heureux de travailler avec elle. Nous sommes également reconnaissants de l'appui extraordinaire de Wendy Chambers qui occupe, depuis six mois, le poste de directrice exécutive intérimaire pour TESL Canada, et Liz Karra, qui a fourni un appui administratif au bureau national. Plusieurs personnes ont joué des rôles spécifiques et cruciaux dans la production de la revue et nous applaudissons leurs habiletés et les remercions de leur engagement.

Les articles dans ce numéro touchent une gamme de sujets qui ont des retombées pour l'enseignement et l'apprentissage de l'ALS au Canada. Le premier, par Antonella Valeo et Farahnaz Faez, présente les résultats d'une enquête et d'entrevues auprès d'enseignants débutants qui ont terminé une formation TESL en Ontario et qui entrent dans la profession d'enseignement de l'ALS aux adultes. Ils décrivent leur formation et leurs expériences professionnelles, l'auto-efficacité d'enseignants d'ALS en début de carrière et la mesure dans laquelle les participants ont pu obtenir des postes appropriés dans leur profession en Ontario dans les trois ans suivant leur accréditation. Cet article est de nature à intéresser les administrateurs, les enseignants, les organismes subventionnaires et les associations professionnelles en ALS.

Sabrina Di Loreto et Kim McDonough partagent les résultats d'une étude menée dans des écoles secondaires d'ALS au Québec. Elles décrivent la mesure dans laquelle les examens de pratique et la rétroaction sur certains aspects de ces examens ont augmenté la confiance des étudiants et ont soulagé leur anxiété face aux examens de synthèse standardisés portant sur la rédaction. On y présente également des suggestions pratiques pour appuyer la préparation des étudiants aux tâches particulières de rédaction, pour encourager la transmission de la rétroaction et pour favoriser la réussite des étudiants.

Sasan Baleghizadeh et Atieh Masoun décrivent les résultats d'une étude entreprise avec des apprenants d'ALE et touchant l'influence de leur autoévaluation formative sur leur auto-efficacité. Les résultats indiquent que les apprenants qui ont complété des auto-évaluations toutes les deux semaines ont amélioré leur auto-efficacité avec le temps. Les auteurs discutent des répercussions et présentent des questionnaires d'auto-évaluation pour des 
cours d'anglais au postsecondaire. Cet article intéressera les enseignants d'ALS et d'ALE pour adultes.

Shira Packer et Dana Lynch explorent les perceptions d'étudiants à l'université et de diplômés récents nés au Canada et nés à l'étranger quant au caractère des Canadiens. Les données découlant de leur enquête et d'entrevues électroniques révèlent quelques différences dans les perceptions chez les deux groupes. Les auteures offrent des suggestions pour encourager l'acculturation des étudiants internationaux au Canada.

Le plagiat est un enjeu qui demuere une préoccupation dans le milieu postsecondaire au Canada. Ismaeil Fazel et Nasrin Kowkabi identifient cinq facteurs potentiels qui contribuent aux épisodes de plagiat par des apprenants en langue seconde. Pour chacun de ces facteurs, les auteurs offrent des conseils pédagogiques fondés sur la littérature et leurs expériences d'enseignement. L'article inclut également des propositions pour des sujets de discussion et des références en ligne pour aider les étudiants à bien citer leurs sources.

Ce numéro contient également des critiques de Marilyn Abbot (portant sur New Language, New Literacy par Jill Bell), de Justine Light (portant sur Reflective Writing for Language Teachers par Thomas Farrell), et de John Sivell et Chirawibha Sivell (portant sur Identity and Language Learning: Extending the Conversation par Bonny Norton). Nous espérons que ces critiques vous donneront envie de lire les œuvres originales de sorte à profiter de la foule d'informations qu'elles offrent aux enseignants d'ALS.

Les pages de cette revue proposent beaucoup de matière à réflexion. Nous recommandons que, à moins d'être membre d'un groupe de lecture professionnel, vous recrutiez quelques collègues avec qui vous choisirez un des articles dans ce numéro pour ensuite vous rencontrer et en discuter. Établissez une heure fixe pour la rencontre, dans un milieu où vous serez à l'aise, et prévoyez du temps social et des rafraichissements. L'identification et la discussion des incidences de l'article choisi sur les cours d'ALS que vous offrez dans votre contexte particulier, vous donneront l'occasion de partager vos propres expériences en salle de classe et de mettre en pratique des éléments qui découlent de la rencontre. Je souhaite que cela devienne une expérience enrichissante dans le cadre de votre formation professionnelle continue. Bonne lecture!

Marian Rossiter 